\title{
Some Aspects of the Translation into Iranian Languages of the Works by Mani
}

\author{
EnRico Morano (Turin/Italien)
}

In his well known proclaim, in which he says that his religion is in 10 points superior to the other religions, Mani clearly states, in the first point, that his religion will be manifest in all countries and in all languages.

M5794+M5761

/7/ ... yk kw dyn 'y/8/[']hyng'n pd yk šhr 'wd yk /9/ 'zw'n bwd oo 'yg dyn 'y mn/10/ "d kw pd hrw šhr 'wd p[d]/11/w(y)sp 'zw'n pyd'g bw'd。

"Firstly: the older religions were in one country and one language. But my religion is of the kind that it will be manifest in every country and in all languages, and it will be taught in far away countries."

[ANDreas / HenNing 1933, p. 295]

It is common opinion that Mani wrote his books in his native Babylonian Aramaic, except for the Šäbuhragān, which was written in Persian for the Sasanian King Šābuhr. Even so, Aramaic was never considered as a sacred language, and during Mani's lifetime, and shortly after his death, his disciples, probably under his supervision, translated all of his writings into Persian and Parthian, the two most important tongues of the empire. These translations, along with other Manichaean books, were taken to Central Asia, and were subsequently translated into Sogdian, Old Turkic and Chinese. It remains a mistery, however, why not a single line in Aramaic was found among the Manichaean Turfan texts.

Translating texts, especially Mani's writings, was a noble, very important, vital task for the Manichaeans. But how did they accomplish the task? Did they use particular techniques?

Discussions of the theory and practice of translation go back to antiquity. The Greeks distinguished between metaphrase (i.e. 'literal' or 'word-for-word', 'formal equivalence') and paraphrase (i.e. 'saying in other words', 'dynamic equiv- 
alence'). Translators of religious texts often must consciously seek to produce a literal translation, in order to adhere as closely as possible to the source text. This seems to be the case, for instance, of the beginning of Mani's Living Gospel, which we have in Middle Persian (M17 and M644) and in Greek (Cologne Mani Codex, $66 \mathrm{ff}$.). In the few lines handed down by the manuscripts, the two translations, possibly from the same Aramaic source, go practically word for word, with the sole exception of the word for 'Christ', which in Persian is always "zoroastrianized" into Aryaman, the Avestan yazata of healing.

\section{Mani's Living Gospel}

M17 and M644 [Middle Persian]

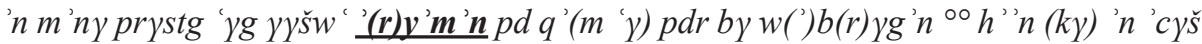
bwd $<$ hym $>\{15$ lines missing\} 'c ps wysp 'st 'wd hrw cy bwd w: bw'd pd 'wy zwr 'ystyd $\{7$ lines left blank\}

'I Mani, apostle of Jesus Aryāmān, by the will of the Father, the true God, he from whom I came to be, [ ... ] [V/ii] is after all (things), and everything which has been and will be stands by his power.'

[MacKenzIE 1995, pp. 184 ff.]

Greek text (CMC)

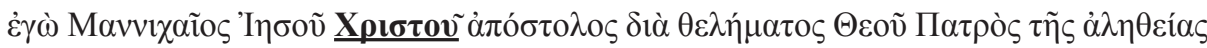

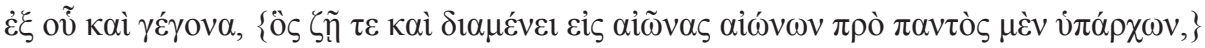

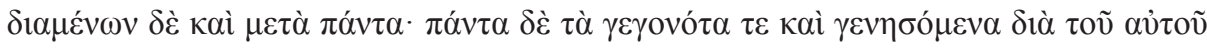
$\sigma \theta \varepsilon \dot{v o v \varsigma} \dot{v} \varphi \varepsilon ́ \sigma \tau \eta \kappa \varepsilon v$.

[KOENEN / RÖMER 1988, pp. 44-46]

Also a litany, part of one of the two Psalms called qšwdg'n 'frywn 'Blessings of the Little Ones', which we have in Parthian and Middle Persian, appears to be translated with extreme fidelity.

$\S 25 \mathrm{a} \cdots \cdots \cdot(\mathrm{n}) \mathrm{w}(\mathrm{ny}) \mathrm{wd}$ 'n 'y'wšt [hwm '... destructions we returned(?).'

$\S 25 \mathrm{~b}$ 'bn's ' $z w s ̌ t h y m$ 'd ${ }^{\circ \circ ~ ' . . . ~ w e ~ r e t u r n e d ~(t o ?) ~ d e s t r u c t i o n . ' ~}$

$\S 26 a$ 'b'g 'byd]g'n 'byd bwd [hwm 'With those in need we became in need.'

$\S 26 \mathrm{~b}$ '[d] 'bydg'n ${ }^{\circ}(\mathrm{b})[y](d) h y m\left({ }^{\prime} d\right)^{\circ}$ 'With the needy we were in need.'

$\$ 27 \mathrm{a} *$ 'b'g wy]ptg'n wy(pt) (hw)[m] 'With the deceived we were deceived.'

$\S 27 \mathrm{~b}$ 'd frnštg:n ${ }^{\circ}$ frn $(\check{s})[t] h y m$ 'd ${ }^{\circ}$ 'With the destroyed ones we were destroyed.' 
§28a ['b'g hnjwg](')n hnjwg bwd hw[m] 'With the anguished ones(?) we became anguished(?).'

$\S 28 \mathrm{~b}$ 'd $\underline{t}^{\prime} r y g^{\prime} n{ }^{\circ} t^{\prime} r y g[b](w \underline{t})(h) y m^{\prime} d{ }^{\circ}$ 'With the dark ones we became dark.'

§29a [pd *wysp'n ](d)w'ryšn:n dw'(r)[yst] [hwm] 'In all the running we ran.'

$\S 29 \mathrm{~b} p d w y s p \mathrm{cmg}^{\circ}(t)[x t h](y) m^{\prime} d^{\circ}$ 'In/on all courses we ran.'

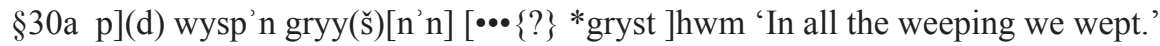

$\S 30 \mathrm{~b} p d$ wysp $b(\mathrm{rm}) \mathrm{g}^{\circ}[\mathrm{b}]\left(\mathrm{rm}^{\prime} d\right) h \gamma^{\circ}(\mathrm{m})^{\prime} d\left(^{\circ}\right)$ 'In/at every weeping we wept.'

$\S 31$ a pd wysp'n [••]\{?\} [prbysyšn]:n (p)rbys'd [hwm] 'In all the injuring we were injured.'

$\S 31 \mathrm{~b} p d w \gamma s(p)[w](x) s\left({ }^{\prime}\right) g{ }^{\circ}(w x) s^{\prime}(d h) y m^{\prime} d^{\circ}$ 'In/at every wounding we were wounded.'

$\S 32 \mathrm{a}[\bullet\{?\}$ * pd *wysp'n ']whng'n [wysp] [••• ‘... in all the sorrows, all ...'

$\S 32 \mathrm{~b}\left({ }^{\prime} w\right) m\left({ }^{\prime}\right) n\left[\bullet \bullet \cdot\left({ }^{\circ}\right)(p) d w \gamma s p{ }^{\prime} w(w) d j(n)^{\circ}\right.$ wysp $\left[\bullet \cdots \cdot(j) n{ }^{\circ}\right.$ 'And us/our ... in every harshness, every ...'

$\S 33 \mathrm{a} \bullet \bullet \mathrm{hr}]\left(\mathrm{w}^{\prime}\right) \mathrm{gw}[\mathrm{c} \bullet \cdot]$ \{one line missing '.. everywhere ...'

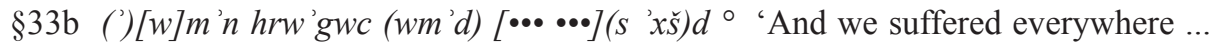
(without?) pity.'

[Durkin-Meisterernst / Morano 2010, pp. 21 ff.]

Were then the Manichaean translators extreme metaphrasers? Already Cicero cautioned against the license of metaphrase:

Conuerti enim ex Atticis duorum eloquentissimorum nobilissimas orationes inter seque contrarias, Aeschini et Demostheni; nec conuerti ut interpres, sed ut orator, sententiis isdem et earum formis tamquam figuris, uerbis ad nostram consuetudinem aptis. In quibus non uerbum pro nerbo necesse habui reddere, sed genus omne uerborum nimque seruaui.

'I have translated the excellent and contrasting orations of two of the most eloquent of the Attics: Aeschines and Demosthenes; nor did I translate them as an interpreter, but as an orator, with the same notions and the same forms and figures, using words appropriate to our usage. In so doing, I did not find it necessary to translate word for word, but I preserved their style and force.'

[Cicero, De optimo genere oratorum, 5, 14-15]

A closer look at texts, of which we have the Middle Persian and the Parthian versions, reveals, however, how clever the Manichaean translators were. 
Henning, while editing (Henning I958, pp. 102-103) one of these bilingual texts, a litany, like the one mentioned above, from the qšwdg'n 'fr $\gamma w n$, had noticed this:

„Denn die iranischen Manichäer, die überhaupt — wenn solch eine Verallgemeinerung erlaubt ist - eine literarische Ader hatten, waren ausnehmend gute Übersetzer; im Gegensatz zu den meisten Leuten des Orients begnügten sie sich nicht damit, das Original 'wörtlich' oder 'zwischenzeilig' wiederzugeben, sie bemühten sich vielmehr, eine sinngemässe, aber gleichzeitig idiomatisch tragbare und gefällige Übersetzung zu erzielen. Von der Wortähnlichkeit, etwa bei den im Mitteliranischen zahlreichen etymologisch identischen Wörtern, liessen sie sich dabei nicht täuschen; wenn die Bedeutungssphäre nicht genau übereinstimmte, wurde ein unähnliches Wort vorgezogen.“

§323a dryst wys ' $y \underline{\text { b šn }} \gamma w m$ wzrg。

'Welcome, my great body!'

\$323b drwd] 'br tw $\circ$ mn th wzrg [०

'Welcome to you, my great body!'

\$324a dryst wys ' $y$ cy(h)rwm b'myw。

'Welcome, my radiant form!'

\$324b drwd] 'br tw $\circ$ p'dgyrb [wm ] nys' gyn $\circ$

'Welcome to you, my shining form!'

§325a $d r y s t w y s^{\prime} y \underline{\text { dys }} w m$ rwc 'g 。

'Welcome, my shining aspect!'

§325b drwd 'b[r tw] cyrgwm rwšn ०

'Welcome to you, my light-form!' [...]

\$331a (d)ryst wys ' $y s w r \underline{\text { 'bz'r } \boldsymbol{r}} \circ k y d w s \underline{t}^{\prime}(n)$ 'cyš phyp 'rwm

'Welcome, powerful banquet, with which I fill (my) friends!

\$331b drwd 'br tw wxrdygwm wzrg ०o 'c kw (')mb'r'm ॰ 'w šyrg'mg'n

'Welcome to you, great banquet, with which I fill (my) friends!

M215 (Parthian) and M842 (Middle Persian)

[Durkin-Meisterernst / Morano 20io, pp. 94 ff.]

1 Ela Filippone kindly informs me that in many New Iranian dialects $b s ̌ n$, besides 'stature, height', often means just 'body'. Among others she quotes: Kurdish Kurmanji bejn 1) 'heigth, stature (of a person)' (syn. qam(et), qedqamet); 2) 'waist' (syn. navteng); bejn [f.] 'corps, taille d'homme'; (Djabal Sindjār) bêjin [f.] 'corps'; Gurani bažn 'taille, corps'; Zaza bejn body (only for height reference)'; central dialects: Kermāni bašn 'body' [tan, lālbād, sar tā pā]; Ravāri bašn 'body'; Sirjāni bašn 'body and limbs' [tan va andām]; bašn-e bar 'all the figure' [tamāme heykal]; Zarqāni bašn, bar o bašn 'body'; Xunsāri bašn 'body'. I would like to thank her heartly for anticipating some results of her still unpublished research. 
Paraphrase vs metaphrase: The beginning of Mani's Psalm: 'ymyn 'hynd 'These are' [Morano 2009 and Durkin-Meisterernst / Morano 2010, pp. 116 ff.]:

In the case of the beginning of the second Psalm by Mani Wuzurgān Áfrīwan 'The Blessings of the Great Ones', we happen to have it in three versions: Middle Persian, Parthian and Sogdian. While the Middle Persian and Parthian ones go almost parallel, the Sogdian version is abridged and somehow condensed to a mere formula. Nevertheless, the Manichaean translators did not fail to show their skill: the figura etymologica 'frywn cy 'fryd (Parthian), ysn ' $y$ yšt (Middle Persian) and "pry-wnh $\mathbf{c w} \boldsymbol{Z} Y$ " $\boldsymbol{p} \boldsymbol{p} \boldsymbol{y}$ - $\boldsymbol{t} \boldsymbol{\delta}$ ' $\boldsymbol{r} \boldsymbol{t}$ "the blessing which he uttered", literally "the blessing which he blessed" is kept in all versions, and in the Middle Persian version the phrase $y s n$ ' $y$ yst, which sounds almost like 'the yasna which he performed', has a strong Zoroastrian flavour.

Compiled Parthian text [M790, Ch/U6546+Ch/So20501, M608b+M895b, M895e]

Headline: ' $y(m y n$ ') [hynd]

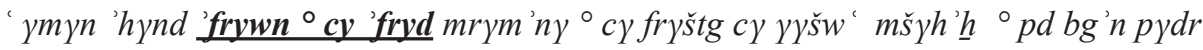
$k^{\prime} m^{\circ} \mathrm{kd}$ ['w?] wzrgyft ${ }^{\circ}$ 'wd hrwyn šhr'n $r^{\prime} z$ 'bgws $(t){ }^{\circ}[c y b w](\gamma d) b w(d) ~ ' s t{ }^{\circ}$ 'wd 'c šhr'n ${ }^{\circ}$ ngwst 'hynd 'bdyšt ${ }^{\circ}$ 'br šhr'n rwšn'n r'z 'br t'ryg'n šhr'n r'z ${ }^{\circ}$ 'wd 'br wmyxtg'n šhr'n [wr]dy̌sn nm'd ' 'wd kd 'ymyn ${ }^{\circ}$ [ngws]tgyft 'bgwst ' 'dy'n ['ymyn 'frywn 'fryd] 'w wzrgyft xwd' $y$ ['wd 'w wysp' $n]$ pydr'n ' 'ymyn [...]

"These a[re] ..."

"These are the Blessings which Mār Mānī, by the will of the Father of Gods apostle of Jesus Christ, recited, when he revealed [the] Greatness and the mystery of the worlds [that will b]e, were, (and) are ${ }^{2}$, and showed (things that) were hidden to the worlds: he showed concerning the mystery of the Light Worlds, concerning the mystery of the Dark Worlds, and concerning the turning of the mixed worlds. And when he revealed these [hidden] things, then [he praised this blessing] to the Lord of Greatness [and to all the] fathers: these [...]"

2 The text at this point is badly damaged in all the manuscripts, and therefore it was heavily emended. The seemingly odd temporal sequence future-past-present, instead of the normal past-present-future, is supported by what follows, in exactly the same sequence: 'he showed concerning the mystery of the Light Worlds (ie. the paradise, what everybody first must aim at), concerning the mystery of the Dark Worlds, and concerning the turning of the mixed worlds'. 
Middle Persian text [M379b]

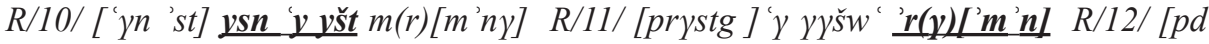

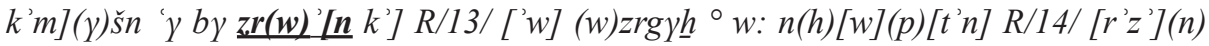
'bhwpt ${ }^{\circ}$ ' $(m)[w x t$ ? ...] R/15/[...](k/x. .)'n 'y b(w)y(d b)[wd 'st] $R / 16 /$ ['wd 'z šhr]'n

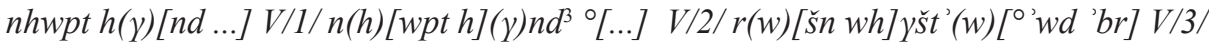

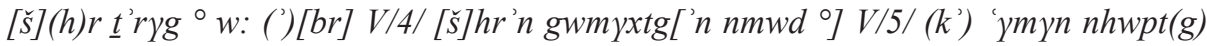

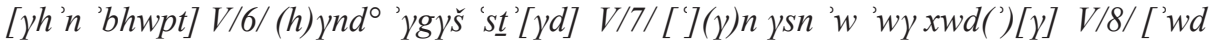

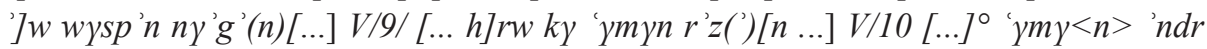

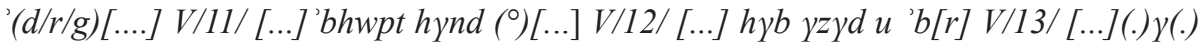
$\circ$ (u) hmys 'w(.)[...] V/14/[...](.) ० '(y) p(d) b'ry(s)[t ...] $V / 15 /[. .(k / x) .] q. y \underline{h}$ 'bzw'(d) [...] (end of page)

"R/10/ [This is] the Blessing recited by Mār[ Mānī], R/11/ [the Apostle] of Jesus Ary[āmān] R/12/ [by the wish] of God Zurwā[n, when] R/13/ [the] Greatness and the secret [things] R/14/ [of the worlds] he revealed. He tau[ght?...] R/15/ [....] which will be [were and are] R/16/ [and which] were hidden [from the worlds] \{end of page $\}$ beginning of page $\} \mathrm{V} / 1 /$ were hidden. 19 [He showed on...] V/2/ [Light Pa]radise [and on the] V/3/ dark [wo]rld, and [on the] V/4/ mixed [wo]rlds. V/5/ When these hidden things were revealed, $\mathrm{V} / 6 /$ then he prai[sed] $\mathrm{V} / 7 /$ [th]is blessing to the Lord $\mathrm{V} / 8 /$ [and] to all Ancestors $[\ldots] \mathrm{V} / 9 /[\ldots]$ all those who [...] these mysteries. V/10/ Those in [...] V/11/ [...] are revealed. V/12/ [....] may ye recite and upon $\mathrm{V} / 13 /$ [...]. And together to $[\ldots] \mathrm{V} / 14 /[\ldots]$. Who in the highest $[.] \mathrm{V} / 15 /[\ldots]$ may increase/ be added to $[\ldots]$ " (end of page)

Sogdian text [So14570/R/]

Headline in verso, (Parthian): ' $y m y n$ ' ' $x y$ - $n t$

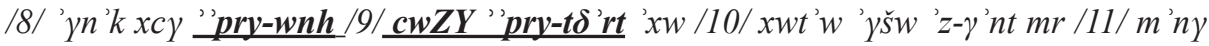
ktxw pr rxwšny' /12/ 'z-ny' z- 'wr 'wst't ${ }^{\circ 0 / 13 / r t y ~ Z K w ~ k w c ~ ' k h ~ p r ~ \gamma w \beta t y ' ~ / 14 / ~ p w r n w ~}$ $k w n t^{\prime} r(t) y w y^{\prime} \beta r Z Y / 15 / w^{\prime} n k w w^{\prime} \beta$ ००

"/8/ This is the Blessing /9/ which the Apostle /10/ of the Lord Jesus Mār /11/ Mānī prayed, when he was established /12/ in the power of the LightKnowledge. /13/ And he filled his mouth with praise and spoke saying: (there follows the actual prayer)"

3 Probably repeated erroneously (dittography). 


\section{Bibliography}

Andreas, Friedrich Carl / Walter Bruno Henning (1933): "Mitteliranische Manichaica aus Chinesisch-Turkestan, II”. In: SPAW, Phil.-hist. Kl., Berlin, pp. 294-363.

Durkin-Meisterernst, Desmond / Enrico Morano (2010): Mani's Psalms. Middle Persian, Parthian and Sogdian Texts in the Turfan Collection. Turnhout (BT 27).

Henning, Walter Bruno (1958): “Mitteliranisch”. In: Bertold Spuler (ed.): Handbuch der Orientalistik. 1. Abt., 4. Bd.: Iranistik. 1. Abschn.: Linguistik. Leiden/Köln, pp. 20-130.

Koenen, Ludwig / Cornelia Römer (1988) (ed.): Der Kölner Mani-Kodex: Über das Werden seines Leibes. Kritische Edition ... Opladen. (Abhandlungen der RheinischWestfälischen Akademie der Wissenschaften. Papyrologica Coloniensia 14).

MacKenzie, David Neil (1994): “»I, Mani...»”. In: Holger Preissler / Hubert SeiWERT (edd.): Gnosisforschung und Religionsgeschichte. Festschrift für Kurt Rudolph zum 65. Geburtstag. Marburg, pp. I83-198.

Morano, Enrico (2009): “ymyn "hynd: The Beginning of Mani’s Psalm Wuzurgān Afrīwan in Parthian and Middle Persian”. In: Jason David BeDuhn (ed.): New Light on Manichaeism. Papers from the Sixth International Congress on Manichaeism. Organized by The International Association of Manichaean Studies. Leiden/Boston, pp. 213-223 [P1. 1-4]. 
